\title{
Effect of glycated collagen on proliferation of human smooth muscle cells in vitro
}

\author{
K. Iino, M. Yoshinari, M. Yamamoto, K. Kaku, Y. Doi, K. Ichikawa, M. Iwase, M. Fujishima \\ Second Department of Internal Medicine, Faculty of Medicine, Kyusyu University, Fukuoka, Japan
}

\begin{abstract}
Summary While non-enzymatic glycation of longlived tissue proteins such as collagen has been implicated in chronic complications of diabetes mellitus, its role in the aetiology of diabetic macroangiopathy has not been elucidated. To test the hypothesis that glycation of collagen abolishes the inhibitory effect of native collagen on the proliferation of human smooth muscle cells, we obtained smooth muscle cells from human gastric arteries and cultured them on dishes coated with glycated or non-glycated collagen. The proliferation of human smooth muscle cells in the presence of $10 \%$ fetal calf serum or platelet derived growth factor-BB $(10 \mathrm{ng} / \mathrm{ml})$ was inhibited by type 1 collagen coated on the dishes. Glycation of collagen with glucose 6-phosphate for 7 days abolished the growth-inhibitory effect of native collagen. Succinylation of collagen, which like glycation blocked the
\end{abstract}

lysyl residues in collagen, also abolished the growthinhibitory effect. Adhesion of human smooth muscle cells to collagen-coated dishes was not affected by glycation of collagen. Addition of glycated albumin to the medium did not affect the growth of human smooth muscle cells on plastic dishes. The inhibition of human smooth muscle cell proliferation by collagen was not reversed by the glycation of collagen in the presence of aminoguanidine. Results suggest that early glycation abolishes the inhibitory effect of collagen on human smooth muscle cell proliferation and may thus participate in the progression of macroangiopathy in diabetes. [Diabetologia (1996) 39: 800806]

Keywords Smooth muscle cell, collagen, aminoguanidine, glycation, atherosclerosis
Macroangiopathy progresses rapidly in patients with diabetes mellitus. While its mechanism is not well understood, it is thought that the smooth muscle cells (SMC) may be involved. Accelerated growth

Received: 22 August 1995 and in revised form: 19 February 1996

Corresponding author: K. Iino, M.D., Second Department of Internal Medicine, Faculty of Medicine, Kyusyu University, Maidashi, 3-1-1, Higashi-ku, Fukuoka-city 812, Japan

Abbreviations: BSA, Bovine serum albumin; FCS, fetal calf serum; DMEM, Dulbecco's modified Eagle's medium; PBS, phosphate buffered saline; TCA, trichloroacetic acid; HSMC, human smooth muscle cell; PDGF, platelet derived growth factor; b-FGF, basic-fibroblast growth factor; AGE, advanced glycation endproduct; G6P, glucose 6-phosphate; TNBS, 2,4,6-trinitrobenzenesulfonic acid; 5-HMF, 5-hydoxymethylfurfural. of aortic SMC from diabetic animals has been reported [1-3]. These cells migrate from the media to the intima of the aorta and proliferate in response to growth factors such as platelet derived growth factor (PDGF) and basic-fibroblast growth factor (b-FGF)[4]. Type 1 collagen, which is abundant in the artery, inhibits the proliferation of SMC $[5,6]$. Recent studies postulate that excessive glycation of proteins is a cause of the vascular complications of diabetes. Advanced glycation end products (AGE) induce the production of interleukin-1 and tumour necrosis factor- $\alpha$ [7] by macrophages. These cytokines have been reported to stimulate the proliferation of SMC [8]. Non-enzymatic glycation alters the properties of collagen for fibroblasts $[9,10]$. To determine whether the inhibitory effect of collagen on the growth of SMC may be abolished in the diabetic state, we investigated the effect of collagen 
glycation on the proliferation of human-SMC (HSMC) in response to fetal calf serum (FCS) or PDGF in vitro.

\section{Materials and methods}

Sterile purified type 1 collagen and culture dishes were purchased from Iwaki Glass (Funabashi, Japan). Dulbecco's modified Eagle's medium (DMEM) and FCS were purchased from Gibco (New York, N. Y., USA) and Nipro (Osaka, Japan), respectively. PDGF-BB, aminoguanidine hydrochloride, succinic anhydride, and all other drugs were purchased from Wako Chemicals (Osaka, Japan). Bovine serum albumin (BSA) (Sigma A0281) was purchased from Sigma Chemical Company (St. Louis, Mo.,USA). Glucose 6-phosphate (G6P) was purchased from Oriental Yeast (Osaka, Japan). ${ }^{3} \mathrm{H}$-methyl thymidine $(80.0 \mathrm{Ci} / \mathrm{mmol})$ was purchased from Amersham (Tokyo, Japan).

Human smooth muscle cell culture. H-SMC were obtained from gastric arteries removed from the stomachs of patients undergoing resection for early gastric cancer. None of these patients had hypertension, diabetes, hyperlipidaemia, or cardiovascular disease. H-SMC were cultured by the explant method in DMEM (pH 7.4) containing $10 \%$ FCS. Five to ten passages were performed for each experiment. H-SMC were identified by their hill and valley appearance and a positive immunofluorescence for $\alpha$-actin [11]. After H-SMC became confluent in a Lab-Tek chamber slide, immunofluorescence staining was performed using mouse monoclonal antibody (ASM1) for $\alpha$-smooth muscle isoform with actin as the first antibody and then with FITC-conjugated goat antimouse $\operatorname{IgG}$ as the second antibody, according to Skalli et al. [11]. All cells were reacted using this antibody to $\alpha$-actin.

Glycation of type 1 collagen and albumin. Purified type 1 collagen $(0.3 \mathrm{mg} / \mathrm{ml})$ was non-enzymatically glycated by incubation in phosphate buffered saline (PBS) at $37^{\circ} \mathrm{C}$ for 1 week in the presence of $20 \mathrm{mmol} / \mathrm{l} \mathrm{G} 6 \mathrm{P}$, with or without $4 \mathrm{mmol} / \mathrm{l}$ aminoguanidine under sterile conditions. As a control, collagen was incubated for 1 week without G6P. The collagen suspensions were subsequently dialysed for $12 \mathrm{~h}$ three times with $0.15 \mathrm{~mol} / 1$ saline to remove free G6P. We used G6P, instead of glucose, to accelerate the process of non-enzymatic glycation $[12,13]$. The concentration of aminoguanidine was determined so as to prevent the formation of AGE. For $20 \mathrm{mmol} / 1 \mathrm{G} 6 \mathrm{P}$, at least $4 \mathrm{mmol} / \mathrm{l}$ aminoguanidine was required to prevent the AGE formation as measured by fluorescence. BSA $(40 \mathrm{mg} /$ $\mathrm{ml})$ was also incubated in PBS for 1 week at $37^{\circ} \mathrm{C}$ in the presence or absence of $20 \mathrm{mmol} / \mathrm{l} \mathrm{G} 6 \mathrm{P}$, and then dialysed. We used a sterile preparation of collagen. The albumin and all reagents were passed through a $0.22 \mu \mathrm{m}$ filter. These samples were then dialysed with autoclaved $0.15 \mathrm{~mol} / \mathrm{l}$ saline and a sterile dialysis membrane.

Succinylated collagen. Type 1 collagen was succinylated with succinic anhydride by the method of Wang et al. [14]. The extent of succinylation of $\varepsilon-\mathrm{NH}_{2}$ groups of lysyl residues in collagen was determined by the method of Kakade and Liener [15]. Briefly, $1 \mathrm{ml}$ of $0.1 \%$ 2,4,6-trinitrobenzenesulfonic acid (TNBS) was added to $1 \mathrm{ml}$ of sample in $4 \% \mathrm{NaHCO}_{3}$ (pH8.5). After incubation at $40^{\circ} \mathrm{C}$ for $2 \mathrm{~h}, 3 \mathrm{ml}$ of concentrated $\mathrm{HCl}$ was added and autoclaved at $120^{\circ} \mathrm{C}$ for $1 \mathrm{~h}$, and then $5 \mathrm{ml}$ of distilled water was added and extracted twice with ethyl ether. The absorbance was read at $346 \mathrm{~nm}$ for the aqueous solution. The blank was carried through the same procedure except that $\mathrm{HCl}$ was added to the samples prior to addition of TNBS. The amount of 'available' lysine (lysyl residues in which the $\varepsilon$-amino group are free) was calculated from a standard curve obtained with $\varepsilon$-trinitrophenyl-L-lysine. The extent of succinylation of $\varepsilon-\mathrm{NH}_{2}$ groups of lysyl residues in collagen was determined by calculating occupied lysine as percentile of available lysine in native collagen.

Extent of glycation and 'available' lysine in native and glycated collagen with or without aminoguanidine. The extent of early glycation was determined by the method of Elder and Kennedy using thiobarbituric acid [16]. After adding $0.5 \mathrm{ml}$ of $1 \mathrm{~mol} / 1$ oxalic acid to $1 \mathrm{ml}$ of sample $(0.3 \mathrm{mg})$, the mixtures were autoclaved at $121^{\circ} \mathrm{C}$ for $1 \mathrm{~h}$, cooled and mixed with $0.5 \mathrm{ml}$ of $40 \%$ trichloroacetic acid (TCA). Samples were centrifuged at $300 \mathrm{~g}$ for $15 \mathrm{~min}$ and $0.5 \mathrm{ml}$ thiobarbituric acid $(0.05 \mathrm{~mol} / \mathrm{l})$ was added to the supernatant. The tubes were incubated at $40^{\circ} \mathrm{C}$ for $30 \mathrm{~min}$ and then at room temperature for $15 \mathrm{~min}$. The absorbance was measured at $443 \mathrm{~nm}$ against blank employing 5-hydoxymethylfurfural (5-HMF) as standard. The degree of AGE modification was measured with a fluorometer (650-10 M; Hitachi, Tokyo, Japan, $370 \mathrm{~nm}$ excitation; $440 \mathrm{~nm}$ emission). PBS was used as blank for fluorometer evaluation of AGE. We corrected the fluorescence values for the hydroxyproline content of collagen and for the milligram of albumin. The 'available' lysine of native and glycated collagen with or without aminoguanidine was determined by the method of Kakade and Liener [15], as described above. The hydroxyproline content was determined by the chloramine-T assay after acid hydrolysing with $6 \mathrm{~mol} / 1 \mathrm{HCl}$ for $24 \mathrm{~h}$ in a $110^{\circ} \mathrm{C}$ oven [17]. The protein concentration was determined by the Coomassie brilliant blue method (Bio Rad protein assay kit; Hercules, Calif.,USA).

Coating of culture dishes with modified collagen. We coated 24well flat-bottom culture dishes with $15 \mu \mathrm{g}$ of collagen, with or without prior glycation, then dried them in air for $3 \mathrm{~h}$. To reconstitute the collagen fibres, the dishes were incubated with $10 \%$ DMEM + FCS for $1 \mathrm{~h}$. The amounts of the unmodified and modified collagen adhering to the culture dishes were determined using hydroxyproline assay [17]. After coating with collagen, the dishes were incubated with $\mathrm{PBS}$ at $37^{\circ} \mathrm{C}$ for $1 \mathrm{~h}$. After aspiration of PBS, the hydroxyproline in collagen remaining on each dish was assayed after acid hydrolysis. There was no difference in the amount of hydroxyproline in any of the dishes coated with collagen, glycated collagen, or collagen glycated with aminoguanidine $(92.8 \pm 5.7,96.7 \pm 4.2$, $95.0 \pm 3.0 \%$, respectively, $n=4$ ). Therefore, the adhesive property of collagen was not altered by glycation.

Adhesion of H-SMC to collagen-coated dishes. H-SMC were subcultured for $24 \mathrm{~h}$ on plastic dishes that were either uncoated or coated with type 1 collagen or glycated collagen. Thereafter, the number of non-adherent cells present in the medium was counted.

Assay of proliferation of $H$-SMC. For measurement of cell number, H-SMC were plated on wells at a density of $2 \times 10^{4} \cdot \mathrm{ml}^{-1} \cdot$ well $^{-1}$. After reaching subconfluence of cell growth in 4 days, the cells were trypsinized and the cell number was counted with a counting chamber (Erma, Tokyo, Japan).

For measurement of DNA synthesis, H-SMC were plated on wells at a density of $2 \times 10^{4} \cdot \mathrm{ml}^{-1} \cdot$ well ${ }^{-1}$. After the subconfluent stage of cell growth was attained in 3 days, the medium was exchanged for serum-free DMEM for the next $24 \mathrm{~h}$. After being stimulated with $10 \%$ DMEM + FCS or DMEM + 
PDGF-BB (10ng/ml) for $24 \mathrm{~h}$, the cells were incubated with $1 \mu \mathrm{Ci}$ of ${ }^{3} \mathrm{H}$-methyl thymidine for the last $4 \mathrm{~h}$ of incubation, then were washed twice with PBS and incubated with $10 \%$ ice cold TCA for $20 \mathrm{~min}$. The cells were washed with $10 \%$ TCA and rinsed twice with PBS. Finally, the cells were dissolved in $200 \mu \mathrm{l}$ of $0.1 \mathrm{~N} \mathrm{NaOH}$. The cell lysate $(100 \mu \mathrm{l})$ was placed in a scintilation counter after being neutralized with $0.1 \mathrm{~N} \mathrm{HCl}$. The glucose concentration during the 'stimulation' period was $5.5 \mathrm{mmol} / \mathrm{l}$ in all experiments.

\section{Statistical analysis}

Data are expressed as mean \pm SD. Comparisons between groups were made with Student's $t$-test or one-way Anova. A level of $p$ less than 0.05 was considered as statistically significant.

\section{Results}

Extent of glycation and 'available' lysine in native and glycated collagen with or without aminoguanidine. The extent of early glycation of collagen was determined by the thiobarbituric acid assay [16]. The amount of Amadori products in each collagen was determined as follows; native collagen: $0.15 \pm 0.01$ nmol 5-HMF/ $\mu \mathrm{g}$ hydroxyproline, glycated collagen: $0.23 \pm 0.01$, collagen glycated with aminoguanidine: $0.21 \pm 0.03$. The extent of glycation of collagen was 1.53 -fold compared to native collagen, which is similar to the results of in vivo experiments reported in a previous investigation [18]. The amount of Amadori products was similar between glycated collagen and collagen glycated with aminoguanidine. Glycated collagen showed an increase in fluorescence intensity that was completely abolished by aminoguanidine (Table1). We measured the 'available' lysine as free $\varepsilon-\mathrm{NH}_{2}$ groups of lysyl residues in collagen incubated with G6P. The $32 \%$ of total 'available' lysyl residues in native collagen was modified by G6P and the modification was not affected by G6P in the presence of aminoguanidine.

Degree of AGE modification of albumin. Fluorescence intensity of glycated albumin was increased compared to normal albumin, and was almost completely abolished by aminoguanidine (normal albumin: $0.660 \pm 0.003$ fluorescence $/ \mathrm{mg}$ albumin, glycated albumin: $0.783 \pm 0.005$, albumin glycated with aminoguanidine: $0.672 \pm 0.005, p<0.001, n=6$ ).

Effect of glycated collagen on adhesion of H-SMC. To investigate the possibility that glycation of collagen affects the adhesion of H-SMC to culture dishes, H-SMC was subcultured for $24 \mathrm{~h}$ on plastic dishes that were either uncoated or coated with type 1 collagen or glycated collagen. Thereafter, the number of non-adherent cells present in the medium was counted. No significant differences were observed in the adhesiveness of
Table 1. Determination of AGE formation by fluorometry in native and modified collagen

\begin{tabular}{ll}
\hline & Fluorescence/ $\mu \mathrm{g}$ hydroxyproline \\
\hline Collagen & $0.100 \pm 0.003$ \\
Collagen glycated & $0.315 \pm 0.005^{\mathrm{a}}$ \\
$\begin{array}{l}\text { Collagen glycated } \\
\text { with aminoguanidine }\end{array}$ & $0.088 \pm 0.002$
\end{tabular}

Values are means \pm SD $(n=8)$

${ }^{a} p<0.001$ vs collagen and collagen glycated with aminoguanidine

Table 2. The effect of glycated collagen on H-SMC adhesion to dishes

\begin{tabular}{ll}
\hline & Cell number $10^{4} / \mathrm{ml}$ \\
\hline Collagen $(-)$ & $0.30 \pm 0.48$ \\
Collagen $(+)$ & $0.33 \pm 0.50$ \\
Collagen glycated & $0.33 \pm 0.50$ \\
Collagen glycated & \\
with aminoguanidine & $0.38 \pm 0.51$ \\
\hline
\end{tabular}

Values are means $\pm \mathrm{SD}(n=10)$

H-SMC $\left(2 \times 10^{4} / \mathrm{ml}\right)$ were seeded on dishes coated without collagen or with collagen, collagen glycated, and collagen glycated with aminoguanidine. Number of non-adherent cells in the culture media were counted after $24 \mathrm{~h}$

H-SMC cultured on uncoated dishes or on dishes coated with native or glycated collagen (Table 2).

Effect of type 1 collagen on $\mathrm{H}$-SMC proliferation. We coated dishes with collagen at increasing amounts $(0-50 \mu \mathrm{g})$, as shown in Figure 1. Native collagen significantly inhibited ${ }^{3} \mathrm{H}$-thymidine uptake in a dosedependent manner by H-SMC stimulated by $10 \%$ FCS; $60 \%$ inhibition was achieved when the amount of collagen reached $50 \mu \mathrm{g} /$ well $(p<0.001, n=8)$ (Fig. 1).

Effect of glycated collagen on ${ }^{3} \mathrm{H}$-thymidine uptake by $H-S M C$ stimulated by $10 \% F C S$ or PDGF-BB. The inhibitory effect of native collagen on ${ }^{3} \mathrm{H}$-thymidine uptake by $\mathrm{H}-\mathrm{SMC}$ stimulated by $10 \%$ FCS was abolished by collagen glycation $(p<0.005, \quad n=11)$ (Fig.2). Aminoguanidine did not reverse the effect of glycated collagen. ${ }^{3} \mathrm{H}$-thymidine uptake by $\mathrm{H}$ SMC stimulated with PDGF-BB $(10 \mathrm{ng} / \mathrm{ml})$ was also inhibited by native collagen, but not by glycated collagen $(p<0.05, n=12)$ (Fig. 3).

PDGF-BB $(10 \mathrm{ng} / \mathrm{ml})$ stimulated the proliferation of $\mathrm{H}-\mathrm{SMC}$ by $92 \%$ of stimulation with $10 \% \mathrm{FCS}$.

Effect of glycated collagen on H-SMC proliferation determined by cell number. The increase in the number of H-SMC stimulated by $10 \%$ FCS was inhibited by native collagen, and was also abolished by glycation of collagen $(p<0.05, n=8)$. The aminoguanidine added to the incubation mixture of collagen with G6P 


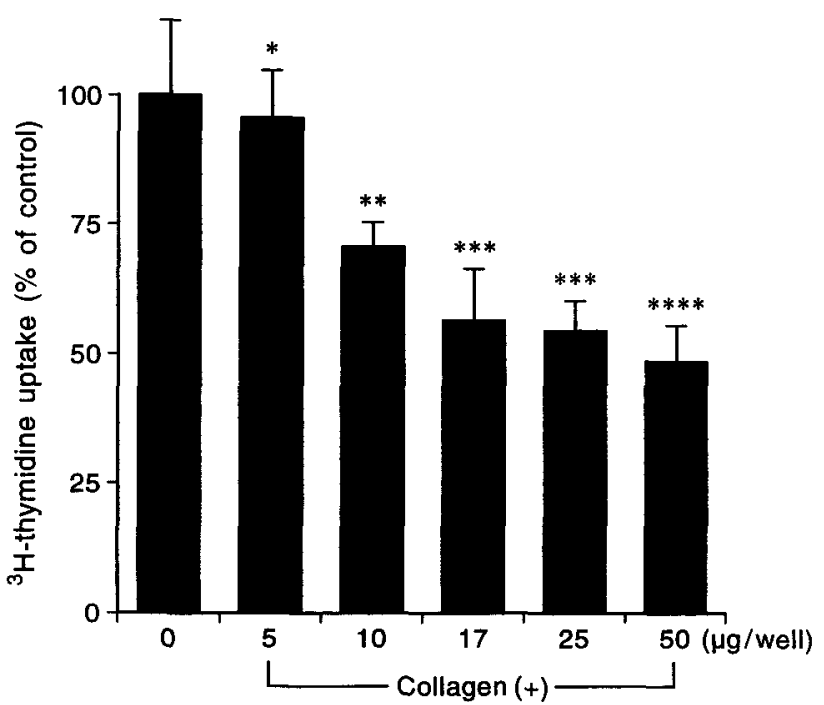

Fig. 1. Dose dependent inhibition by native collagen of ${ }^{3} \mathbf{H}$ thymidine uptake into $\mathrm{H}-\mathrm{SMC}$ stimulated by $10 \%$ FCS. We coated native collagen on the 24-well dishes at increasing doses $(0-50 \mu \mathrm{g})$. The data indicate the percent of ${ }^{3} \mathrm{H}$-thymidine taken up by cells cultured on plastic dishes $(n=8)$. ${ }^{*}$ N.S.; ${ }^{* *} p<0.01$; $* * * p<0.005 ; * * * * p<0.001$

did not reverse the stimulating effect of glycated collagen on the growth of H-SMC (Table 3).

Effect of succinylated collagen on ${ }^{3} \mathrm{H}$-thymidine uptake by $H-S M C$ stimulated with PDGF-BB. The extent of succinylation of $\varepsilon-\mathrm{NH}_{2}$ groups in lysyl residues of succinylated collagen was $61 \%$. Succinylated collagen $(50 \mu \mathrm{g} / \mathrm{well})$ abolished the inhibitory effect of native collagen $(50 \mu \mathrm{g} / \mathrm{well})$ on ${ }^{3} \mathrm{H}$-thymidine uptake by $\mathrm{H}-\mathrm{SMC}$ stimulated with PDGF-BB $(10 \mathrm{ng} / \mathrm{ml})$ to the level of control without collagen $(p<0.005$, $n=8$ ) (Fig. 4).

Effect of glycated albumin on ${ }^{3} \mathrm{H}$-thymidine uptake by $H-S M C$ cultured on uncoated plastic dishes. The addition of $1 \mathrm{mg} / \mathrm{ml}$ of albumin into the medium had no effect on ${ }^{3} \mathrm{H}$-thymidine uptake by $\mathrm{H}-\mathrm{SMC}$ stimulated with $10 \%$ FCS $(p<0.005, n=8)$ (Fig. 5$)$. Also, $1 \mathrm{mg} /$ $\mathrm{ml}$ of albumin glycated with or without aminoguanidine showed no effect on H-SMC growth. There was no difference in H-SMC growth between the native albumin and the glycated albumin in the media.

\section{Discussion}

SMC may play an influential role in the progression of diabetic macroangiopathy. Accelerated growth of aortic SMC from diabetic animals has been reported [1-3]. In atherosclerosis, the SMC migrates from the media to the intima of the aorta and proliferates in response to growth factors such as PDGF and b-FGF [4].

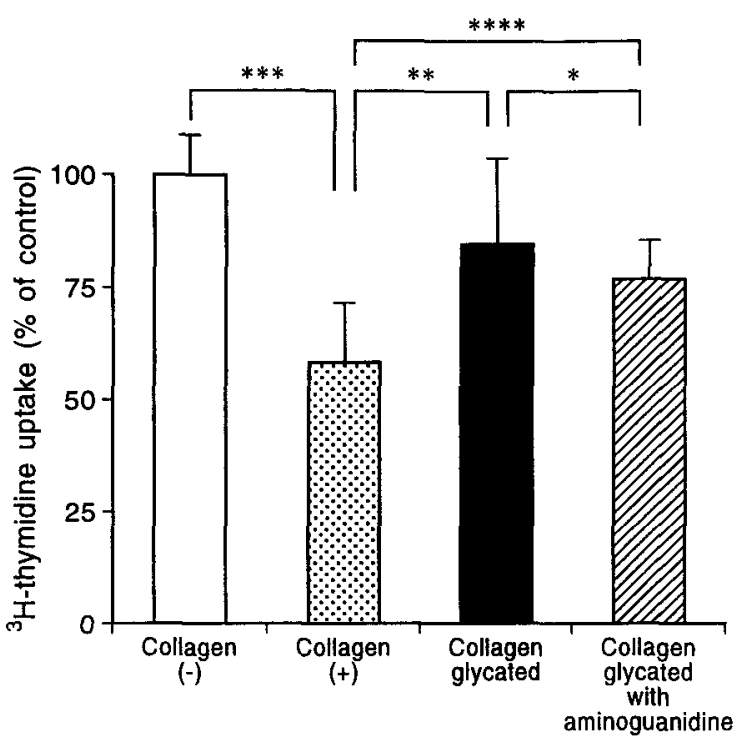

Fig. 2. Effect of glycated collagen on ${ }^{3} \mathrm{H}$-thymidine uptake into $\mathrm{H}$-SMC stimulated by $10 \%$ FCS. Native collagen inhibited $\mathrm{H}$ SMC proliferation on plastic dishes. Glycated collagen abolished the inhibitory effect of native collagen. Aminoguanidine did not prevent the effect of glycated collagen $(n=11)$. ${ }^{*}$ N.S.; $* * p<0.005 ; * * * p<0.001 ; * * * * p<0.05$

Collagen acts as a substrate for SMC and influences activities such as cell morphology, growth, and differentiation [19]. Cells from an atherosclerotic vessel synthesize type 1 collagen in preference to type 3 collagen, unlike the cells of normal arteries [20-22]. Thie et al. $[5,6]$ reported that type 1 collagen inhibits proliferation of SMC. A contractile phenotype of SMC does not respond to serum mitogens [23]. The proliferation of SMC in a three dimensional culture system of collagen matrix was slowed down, as compared with that in monolayer cultures, even though SMC were in an anabolic state [5]. An increased cross-linking of type 1 collagen has been observed in animals and humans with diabetes [24-26].

The effect of non-enzymatic glycation on the physical and chemical properties of collagen has been studied extensively $[9,10,27]$. A decreased adhesion of aortic endothelial cells and an increased adhesion of human monocytes to collagen layers has been reported after non-enzymatic glycation of collagen [28-30]. The growth of mesangial cells is affected by the glycation of extracellular matrices [31, 32]. In these studies, the proliferation of mesangial cells was inhibited by glycated matrices. Since matrices instead of collagen were glycated with $200 \mathrm{mmol} / \mathrm{l}$ G6P for 2 weeks, the AGE formation in these matrices would be further advanced compared to ours with $20 \mathrm{mmol} / \mathrm{l} \mathrm{G} 6 \mathrm{P}$ for 1 week.

Since SMC in an atherosclerotic vessel appear to function like fibroblasts [33], we investigated the effect of glycation of collagen on proliferation of SMC stimulated by FCS or PDGF-BB. A recent study demonstrated an effect of AGE on SMC proliferation 


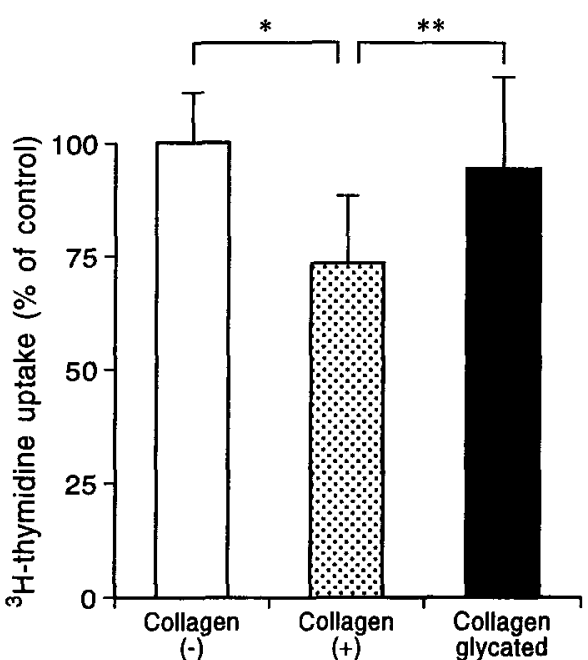

Fig. 3. Effect of glycated collagen on ${ }^{3} \mathrm{H}$-thymidine uptake into $\mathrm{H}-\mathrm{SMC}$ stimulated by $10 \mathrm{ng} / \mathrm{ml}$ of PDGF-BB. Glycated collagen abolished the inhibitory effect of native collagen. $* * p<0.05, n=12 ; * p<0.001$

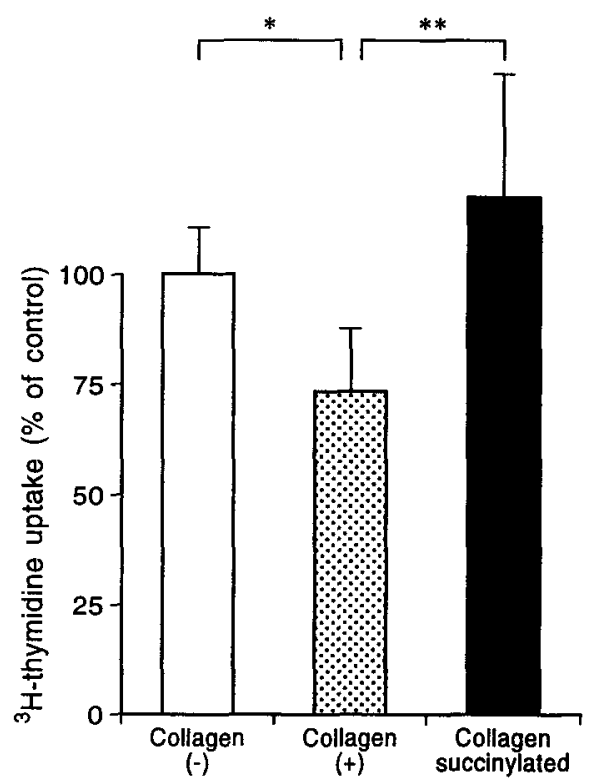

Fig.4. Effect of succinylated collagen on H-SMC growth. In contrast to native collagen $(50 \mu \mathrm{g} / \mathrm{well})$, succinylated collagen $(50 \mu \mathrm{g} /$ well $)$ did not inhibit ${ }^{3} \mathrm{H}$-thymidine uptake into $\mathrm{H}$-SMC stimulated by PDGF-BB $(10 \mathrm{ng} / \mathrm{ml}) .{ }^{* *} p<0.005, n=8$; ${ }^{*} p<0.001$

[34]; collagen-bound AGE were found to block the cytostatic effect of nitric oxide on aortic SMC. These results differ from the direct inhibitory effect of collagen on SMC growth found in our study in that they showed an inhibitory effect of AGE in basement membrane on the cytostatic effect of nitric oxide derived from endothelial cells. The reason for the discrepancy between our data and theirs might be due to the difference in experimental conditions. First, they used a higher concentration of collagen

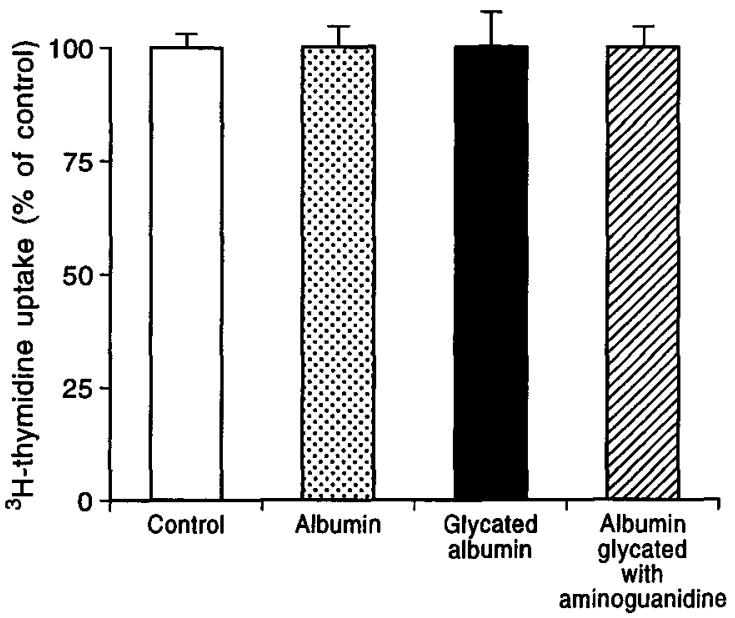

Fig.5. Effect of albumin and glycated albumin on the proliferation of H-SMC stimulated by $10 \%$ FCS. There were no differences in ${ }^{3} \mathrm{H}$-thymidine uptake into H-SMC $(n=8)$.

Table 3. The effect of glycated collagen on H-SMC proliferation stimulated by $10 \%$ FCS

\begin{tabular}{ll}
\hline & Cell number $\left(10^{4} / \mathrm{ml}\right)$ \\
\hline Collagen $(-)$ & $18.1 \pm 5.3^{\mathrm{a}}$ \\
Collagen $(+)$ & $12.7 \pm 3.5$ \\
Collagen glycated & $21.0 \pm 8.7^{\mathrm{a}}$ \\
Collagen glycated & $18.5 \pm 5.9^{\mathrm{a}}$ \\
with aminoguanidine &
\end{tabular}

Values are means $\pm \mathrm{SD}(n=8)$

$\mathrm{H}-\mathrm{SMC}\left(2 \times 10^{4} / \mathrm{ml}\right)$ were seeded on dishes coated without collagen or with collagen, collagen glycated, and collagen glycated with aminoguanidine. After 4 days culture with $10 \%$ FCS + DMEM, cell number was counted

${ }^{\mathrm{a}} p<0.05$ vs collagen $(+)$

$(5 \mathrm{mg} / \mathrm{ml})$ and $\mathrm{G} 6 \mathrm{P}(500 \mathrm{mmol} / \mathrm{l})$ than we did and the incubation time was much longer than ours (60 days). Second, their incubation time for cell culture was only $48 \mathrm{~h}$, which was shorter than our 5 days. We think this was too short, since at least 4 days was required to produce the effect of glycated collagen on growth of SMC in our study. Although AGE may modulate macrophage and endothelial cell function, [7,35-37], AGE albumin had no effect on proliferation of SMC in our study.

Blocking collagen fibril formation by succinic anhydride suppresses the inhibition of fibroblast proliferation by native collagen [38]. It is also known that modification of lysyl residues of laminin abolishes neurite outgrowth [39]. The $\varepsilon$-amino groups in lysyl residues of collagen, which are considered to be essential for the interaction with fibroblasts, are modified by the succinylation [38]. In our study, the modification of lysyl residues of collagen by succinic anhydride suppressed the inhibition of $\mathrm{H}$-SMC proliferation by native collagen. To ascertain the importance of lysyl residues of type 1 collagen for the inhibitory effect of proliferation of H-SMC, we measured the 
'available' lysine as free $\varepsilon-\mathrm{NH}_{2}$ groups of lysyl residues in collagen incubated with G6P. The $32 \%$ of 'available' lysyl residues in native collagen was modified by G6P, which included the new modification not only by Amadori formation (ketoamine) but also by formation of schiff base and AGEs. Therefore, inhibition of proliferation of SMC by type 1 collagen in the intact arterial matrix could be impaired by early glycation of collagen. This may make the SMC susceptible to serum mitogens. The mechanism by which collagen inhibits $\mathrm{H}$-SMC proliferation in response to growth factors has not been elucidated. Lin et al.[40] reported a decrease in the level of PDGF-stimulated receptor autophosphorylation by fibroblasts in collagen matrices. Native collagen may inhibit the growth factor inducing cascade either at or downstream from the receptor site.

Aminoguanidine inhibits cross-linking of glycated collagen, but not the formation of Amadori products[41-43]. In our study, the extent of Amadori product formation was same between glycated collagen and collagen glycated with aminoguanidine. Treatment of glycated collagen with aminoguanidine did not reduce the effect of glycated collagen on proliferation of H-SMC. Recently, the influence of Amadori glucose adducts on cell growth has been reported [44, 45]. A block of lysyl residues essential to inhibit SMC proliferation abolished the physiological function of native collagen in our study. Therefore, early glycation is sufficient to impair the normal function of collagen.

Our results indicate that the suppressive action of native collagen fibril on the proliferation of $\mathrm{H}-\mathrm{SMC}$ was abolished by the glycation of collagen. Early glycation that blocks lysyl residues of collagen may be sufficient to abolish the effect of collagen. The glycation of collagen caused by hyperglycaemia may accelerate diabetic macroangiopathy via an enhanced growth of SMC.

Acknowledgements. We are grateful to Dr. R. Mibu of the First Department of Surgery in our University for his generosity in providing specimens.

\section{References}

1. Kawano M, Koshikawa T, Kanzaki T, Morisaki N, Saito Y, Yoshida S (1993) Diabetes mellitus induces accelerated growth of aortic smooth muscle cells: association with overexpression of PDGF $\beta$-receptors. Eur J Clin Invest 23: 8490

2. Hauss WH, Denes R, Mey J, Lehmann R (1979) Particularities of the vessel wall cells in experimental diabetes. Front Matrix Biol 7: 183-192

3. Alipui C, Tenner TE, Ramos K (1991) Rabbit aortic smooth muscle cell culture. A model for the pharmacological study of diabetes induced alterations in cell proliferation. J Pharmacol Methods 26: 211-222

4. Ross R, Glomset JA (1976) The pathogenesis of atherosclerosis. N Engl J Med 295: 369-377, 420-425
5. Thie M, Schlumberger W, Semich R, Rauterberg J, Robenek H (1991) Aortic smooth muscle cells in collagen lattice culture: effects on ultrastructure, proliferation and collagen synthesis. Eur J Cell Biol 55: 295-304

6. Thie M, Harrach B, Schonherr E, Kresse H, Robenek H, Rauterberg J (1993) Responsiveness of aortic smooth muscle cells to soluble growth mediators is influenced by cellmatrix contact. Arterioscler Thromb 13: 994-1004

7. Vlassara H, Brownlee M, Manogue K, Dinarello C, Pasagian A (1988) Cachectin/TNF and IL-1 induced by glucose-modified proteins: a role in normal tissue remodelling. Science 240: 1546-1548

8. Libby P, Warner SJC, Friedman GB (1988) Interleukin 1: a mitogen for human vascular smooth muscle cells that induces the release of growth-inhibitory prostanoids. J Clin Invest 81: 487-498

9. Kawano E, Takahashi S, Sakano Y, Fujimoto D (1990) Nonenzymatic glycation alters properties of collagen as a substratum for cells. Matrix 10: 300-305

10. Nishikawa A, Taira T, Yoshizato K (1988) In vitro maturation of collagen fibrils modulates spreading, DNA synthesis, and collagenolysis of epidermal cells and fibroblasts. Exp Cell Res 171: 164-177

11. Skalli O, Ropraz P, Trzeciak A, Benzonana G, Gillessen D, Gabbiani G (1986) A monoclonal antibody against $\alpha$ smooth muscle actin: A new probe for smooth muscle differentiation. J Cell Biol 103: 2787-2796

12. Kohn RR, Cerami A, Monnier VM (1984) Collagen aging in vitro by nonenzymatic glycosylation and browning. Diabetes 33: $57-59$

13. Furth AJ (1988) Methods for assaying nonenzymatic glycosylation. Anal Biochem 175: 347-360

14. Wang CL, Miyata T, Weksler B, Rubin AL, Stenzel KH (1978) Collagen induced platelet aggregation and release. I Effect of side-chain modifications and role of arginyl residues. Biochim Biophys Acta 544: 555-567

15. Kakade ML, Liener IE (1969) Determination of available lysine in proteins. Anal Biochem 27: 273-280

16. Elder E, Kennedy L (1983) Rapid, accurate colorimetric assay of non-enzymatically glycosylated serum proteins. Diabetologia 24: 70-71

17. Edwards CA, O'Brien WD Jr, (1980) Modified assay for determination of hydroxyproline in a tissue hydrolyzate. Clin Chim Acta 104: 161-167

18. Rosenberg H, Modrak JB, Hassing JM, Al-Turk WA, Stohs SJ (1979) Glycosylated collagen. Biochem Biophys Res Commun 91: 498-501

19. Kleinman HK, Klebe RJ, Martin GR (1981) Role of collagenous matrices in the adhesion and growth of cells. J Cell Biol 88: 473-485

20. McCullagh KG, Balian G (1975) Collagen characterization and cell transformation in human atherosclerosis. Nature 258: $73-75$

21. McCullagh KG, Duance VC, Bishop KA (1980) The distribution of collagen types I, III and V (AB) in normal and atherosclerotic human aorta. Am J Pathol 130: 4555

22. Murata K, Motoyama T, Kotake C (1986) Collagen types in various layers of the human aorta and their changes with the atherosclerotic process. Atherosclerosis 60: 251-262

23. Chamley-Campbell JH, Campbell GR, Ross R (1981) Phenotype-dependent response of cultured aortic smooth muscle to serum mitogens. J Cell Biol 89: 379-383

24. Chang K, Uitto J, Rowold EA, Grant GA, Kilo C, Williamson $J$ (1980) Increased collagen cross-linkages in experimental diabetes. Reversal by beta-aminopropionitrile and D-penicillamine. Diabetes 29: 778-781 
25. Monnier VM, Kohn RR, Cerami A (1984) Accelerated age-related browning of human collagen in diabetes mellitus. Proc Natl Acad Sci USA 81: 583-587

26. Kent MJC, Light ND, Bailey AJ (1985) Evidence for glucose-mediated covalent cross-linking of collagen after glycosylation in vitro. Biochem J 225: 745-752

27. Tanaka S, Avigad G, Brodsky B, Eikenberry EF (1988) Glycation induces expansion of the molecular packing of collagen. J Mol Biol 203: 495-505

28. Krantz S, Lober M, Thiele M, Teuscher E (1988) Diminished adhesion of endothelial aortic cells on fibronectin and collagen layers after nonenzymatic glycation. Exp Clin Endocrinol 91: 155-160

29. Haitoglou CS, Tsilibary EC, Brownlee M, Charonis AS (1992) Altered cellular interactions between endothelial cells and nonenzymatically glucosylated laminin/type $4 \mathrm{col}-$ lagen. J Biol Chem 267: 12404-12407

30. Gilcrease MZ, Hoover RL (1992) Human monocyte interactions with non-enzymatically glycated collagen. Diabetologia 35: 160-164

31. Crowley ST, Brownlee M, Edelstein D et al. (1991) Effects of nonenzymatic glycosylation of mesangial matrix on proliferation of mesangial cells. Diabetes 40: 540-547

32. Skolnik EY, Yang Z, Makita Z, Radoff S, Kirstein M, Vlassara H (1991) Human and rat mesangial cell receptors for glucose-modified proteins: potential role in kidney tissue remodelling and diabetic nephropathy. J Exp Med 174: 931-939

33. Rauterberg J, Allam S, Brehmer U, Wirth W, Hauss WH (1977) Characterization of the collagen synthesized by cultured human smooth muscle cells from fetal and adult aorta. Hoppe Seylers Z Physiol Chem 358: 401-407

34. Hogan M, Cerami A, Bucala R (1992) Advanced glycosylation endproducts block the antiproliferative effect of nitric oxide. J Clin Invest 90: 1110-1115

35. Kirstein M, Brett J, Radoff S, Ogawa S, Stern D, Vlassara H (1990) Advanced protein glycosylation induces transendothelial human monocyte chemotaxis and secretion of platelet-derived growth factor: role in vascular disease of diabetes and aging. Proc Natl Acad Sci USA 87: 9010-9014
36. Esposito C, Gerlach H, Brett J, Stern D, Vlassara H (1989) Endothelial receptor-mediated binding of glucose-modified albumin is associated with increased monolayer permeability and modulation of cell surface coagulant properties. J Exp Med 170: 1387-1407

37. Kirstein M, Aston C, Vlassara H (1990) Normal human monocytes express insulin-like growth factor 1 (IGF-1) in response to matrix glycation: role in tissue remodelling. FASEB J 4: 1759A

38. Yoshizato K, Taira T, Yamamoto N (1985) Growth inhibition of human fibroblasts by reconstituted collagen fibrils. Biomed Res 6: 61-71

39. Sephel GC, Tashiro K, Sasaki M, Kandel S, Yamada Y, Kleinman HK (1989) A laminin-pepsin fragment with cell attachment and neurite outgrowth activity at distinct sites. Dev Biol 135: 172-181

40. Lin YC, Grinnell F (1993) Decreased level of PDGF-stimulated receptor autophosphorylation by fibroblasts in mechanically relaxed collagen matrices. J Cell Biol 122: 663672

41. Brownlee M, Vlassara H, Kooney A, Ulrich P, Cerami A (1986) Aminoguanidine prevents diabetes-induced arterial wall protein cross-linking. Science 232: 1629-1632

42. Fu MX, Wells-Knecht KJ, Blackledge JA, Lyons TJ, Thorpe SR, Baynes JW (1994) Glycation, glycoxidation, and crosslinking of collagen by glucose. Kinetics, mechanisms, and inhibition of late stages of the Maillard reaction. Diabetes 43: 676-683

43. Makita Z, Vlassara H, Rayfield E et al. (1992) Hemoglobin-AGE: a circulating marker of advanced glycosylation. Science 258: 651-653

44. Cohen MP, Ziyadeh FN (1994) Amadori glucose adducts modulate mesangial cell growth and collagen gene expression. Kidney Int 45: 475-484

45. Cohen MP, Hud E, Wu VY, Ziyadeh FN (1995) Glycated albumin modified by Amadori adducts modulates aortic endothelial cell biology. Mol Cell Biochem 143: 73-79 